\title{
Public engagement in Japanese policy-making: A history of the genetically modified organisms debate
}

\author{
$\operatorname{AUTHOR}(\mathrm{S})$ :
}

Shineha, Ryuma; Kato, Kazuto

\section{CITATION:}

Shineha, Ryuma ...[et al]. Public engagement in Japanese policy-making: A history of the genetically modified organisms debate. New Genetics and Society 2009, 28(2): 139-152

\section{ISSUE DATE:}

2009-06

URL:

http://hdl.handle.net/2433/89520

\section{RIGHT:}

c 2009 Informa plc. 許諾条件により本文は2010-07-01に公開.; この論文 は出版社版でありません。引用の際には出版社版をご確認ご利用くだ さい。; This is not the published version. Please cite only the published version. 
Public engagement in Japanese policy-making: A history of the genetically modified organisms debate

\title{
Ryuma Shineha ${ }^{1}$ and Kazuto Kato ${ }^{1.2}$
}

${ }^{1}$ Graduate School of Biostudies, Kyoto University, Japan.

${ }^{2}$ Institute for Research in Humanities, Kyoto University, Japan.

Contact Information:

RYUMA SHINEHA

TEL: +81-75-753-9244

FAX: +81-75-753-9245

e-mail: shineha@lif.kyoto-u.ac.jp

KAZUTO KATO

TEL: +81-75-753-9246

FAX: +81-75-753-9245

e-mail: kato@zinbun.kyoto-u.ac.jp

Correspondence should be addressed to: shineha@lif.kyoto-u.ac.jp

\begin{abstract}
New laws regulating the use of genetically modified organisms have recently been enacted in Japan, and there were many stakeholders involved in the development of this policy. Our review of the history and the debates held in the course of policy development regarding genetically modified organisms in Japan shows that the current regulatory system was developed taking past national and international regulatory contexts into consideration. The turning point in Japanese policy-making occurred early in this decade, at which time public engagement became an important theme. However, our review also demonstrates that this public engagement did not impact on policies, and that a discussion on how best to evaluate public engagement on policy-making in Japan is still required.
\end{abstract}




\section{Introduction}

After the establishment of a genetic modification (GM) technique in 1973, GM techniques became an essential technique in the life sciences arena and the use of genetically modified organisms (GMOs) has spread rapidly ever since. As of the mid-1990s, the commercial cultivation of GM crops has become increasingly important. James (2007) tells us that the International Service for the Acquisition of Agri-Biotech Applications reported that the cultivation of GM crops - currently cultivated on approximately 100 million hectares in 22 countries- is increasing rapidly. Although Europeans tend to acknowledge the usefulness of GMOs, their application, particularly to comestibles, continues to elicit a negative response from the public (Bredahl 1999; Gaskel et al. 2000, 2006).

In Japan, the Ministry of Health, Labor, and Welfare (MHLW) had, by February 2008, authorized the introduction of 88 GM food products and 14 GM additives. In addition, the sale of comestibles derived from GM techniques, cloning, and cell fusion, increased more than 10 times between 2002 and 2003 (METI, 2006).

The increased use of GMOs in general, and the rapid spread of GM comestibles in particular, has prompted public unease in Japan and led to controversy regarding potential adverse effects on human health, on the environment, on the economy. Ethics and religious issues were also raised (Uzogara 2000, Jo et al. 2003). Several surveys have shown that Japanese consumers react negatively to the use of GMOs (Macer 1992, Kato and Macer 1994, Hoban 1997, Macer and Ng 2000, Ng et al. 2000, Inaba 2003, STAFF 2006). Concerns surrounding bovine spongiform encephalopathy (BSE) or "mad cow disease" and the contamination of GM corn by non-GM corn also damaged the public's trust in scientists and the government (Watanabe et al. 2004).

In view of this heightened public unease and the subsequent debates surrounding the use of GMOs, the promulgation of laws and guidelines regulating their use has become an important issue worldwide. In Japan, the Law Concerning the Conservation and Sustainable Use of Biological Diversity through Regulation on the Use of Living Modified Organisms (the Cartagena Domestic Law) and the Food Safety Basic Law were enacted in May and June 2003 respectively. Related guidelines were later enacted. The enactment of these laws constitutes the most important event in the current Japanese regulatory system concerning GMOs and relevant debates involved a wide variety of stakeholders, including scientists, sociologists, policy-makers, and lay-persons (Ichikawa 2002, Yamanouchi 2005, 2007). 
The dearth of knowledge regarding the history and content of the Cartagena Domestic Law, the Food Safety Basic Law, and other related laws and guidelines led us to investigate the history and the content of debates of the current Japanese regulatory system concerning GMOs through a review of conference minutes (see TABLE. 1 for a list of the relevant agencies).

TABLE. 1 to be inserted here

\section{An outlines of laws and guidelines regulating GMOs in Japan}

In Japan, the use of GMOs is regulated by the Cartagena Domestic Law and the Food Safety Basic Law (Figure 1).

The Cartagena Domestic Law regulates research into and the development of GMOs according to their use and transportation. Two types of GMO use are described; Type 1 use applies to GMOs employed on agricultural lands and Type 2 use applies to GMOs employed in laboratories. Applicants planning to use GMOs must document proper containment measures.

The foundation of the Food Safety Commission (FSC) rests on the Food Safety Basic Law. The FSC evaluates the overall safety of GM foods, GM animal feed, and GM additives in Japan. Safety evaluations are based on standards enacted by the FSC Genetically Modified Foods Expert Committee (FSC-GMFEC).

FIGURE. 1 it to be inserted here

\section{History of Japanese policy-development concerning GMOs}

In this section, we briefly describe the history of Japanese laws regulating the use of GMOs (FIGURES 2 \& 3).

The early 1970s saw the beginnings of political discussion focused on life-sciences in Japan (Saito 1995). Recombinant DNA (rDNA) techniques appeared in 1973 and this technology aroused controversy regarding the technique's potential adverse effects on human health and the environment. In 1975, an international conference on rDNA molecules - the Asilomar conference - was convened to discuss the potential risks and proper use of rDNA techniques and to investigate the establishment 
of guidelines on rDNA research. In 1976, the National Institutes of Health (NIH) of the United States promulgated the Guidelines for Research Involving rDNA Molecules. In Japan, debates concerning the regulation of rDNA techniques started in 1975 and in 1979, the Japanese Ministry of Education and the Science and Technology (S\&T) Agency published its own Guidelines for rDNA Experimentation based on these NIH guidelines. The Japanese guidelines underwent several revisions and formed the basis of subsequent rules guiding the research on and development of GM in Japan.

In the 1980s and 1990s, following the rapid, widespread application of this new technology in medicine, industry, and agriculture, a variety of guidelines were enacted by international organizations such as the Organization for Economic Cooperation and Development (OECD). Several new guidelines were also enacted in Japan. These included the Guidelines for the Industrialization of rDNA Technology, and the Guidelines for Application of rDNA Organisms in Agriculture, Forestry, Fisheries, the Food Industry and Other Related Industries.

A new perspective on the debate regarding GM technology opened up in the late 1980s - the need for the conservation of biological diversity. The Convention on Biological Diversity was convened in 1992 and representatives from different countries and organizations began debating the enactment of international laws to protect biological diversity from potential risks posed by the use of GMOs. In 2000, the Cartagena Protocol was implemented to regulate the international use of GMOs and many countries enacted domestic laws regulating their use. Between 2001 and 2002, four Japanese ministries (MAFF, MEXT, METI and MOE, see abbreviation list of TABLE. 1) began debating new domestic laws to regulate the use of GMOs; they took into both account existing international guidelines and agreements established by international organizations such as the OECD and World Trade Organization (WTO) and domestic regulations. In 2003, the Cartagena Domestic Law was approved. It came into force in 2004.

FIGURE. 2. to be inserted here

In the late 1990s, the use of GM comestibles and GM animal feed raised many controversies as well as giving rise to legal changes in Japan. As a result, the Guidelines for Foods and Food Additives Produced by the recombinant DNA Techniques was enacted by MHW. The first evaluation of the safety of GM foods was conducted by the MHW in 1996 although initial safety assessments were voluntary. By the end of the decade, there were demands for the mandatory testing and labeling of GM foods by 
consumer organizations and the public (Ichikawa 2002, Sasa and Watanabe 2006). In response, political debates regarding the mandatory safety testing and labeling of GM foods began (Uozum 1999, Saegusa 1999a, 1999b, 2000). By 2001, safety testing and labeling of GM foods and feeds became mandatory; enforcement came through a revision of the Food Sanitation Law, the Law Concerning Standardization and Proper Labeling of Agricultural and Forestry Products (JAS Law) (Hino 2002), and the Feed Safety Law (Matsuo et al. 2008). In the same year, the first incidence of mad cow disease - or BSE - in Japan severely damaged the public's trust in the government's ability to ensure food safety, as had happened already in Europe (Gaskel 2004; Watanabe et al. 2004, Jasanoff 2005). To regain public trust, the Research and Examination Committee Regarding the BSE (bovine spongiform encephalopathy) Problem (RECRBP) was established. Its report triggered significant change in Japanese food safety policy as well as recommending that the government found a new regulatory system and install a new independent administration to address food safety (RECRBP 2002). Consequently, the Food Safety Basic Law was enacted and the FSC and its sub-committee, the FSC-GMFEC, were established in 2003. This committee initiated debates on the enactment of safety evaluation standards for GM foods and animal feed based on existing domestic and international guidelines, particularly those published in 2003 by the CODEX Ad Hoc Intergovernmental Task Force on Foods Derived from Biotechnology (TFFDB). During the enactment of TFFDB guidelines, Japan played an important role as the host country of TFFDB (Matsuo 2008). In 2004, the FSC-GMFEC published their evaluation standards.

FIGURE. 3. To be inserted here

In summary, full-scale Japanese policy-development regarding research on GMOs and their use in comestibles began around 2001. Establishment of the current Japanese regulatory system regarding GMOs was based in the domestic and international political context of the previous 30 years.

In preparation for the enactment of the Cartagena Domestic Law, the Food Safety Basic Law, and related guidelines, debates concerning public engagement were also held. This was an important change in the policy development of Japanese science and technology because few such discussions had occurred previously. Despite this recognition of the importance of public engagement in biotechnology policy development, however, there is still a lack of public involvement. Jasanoff, for example, (2005) has referred to the incomplete democratic politics of biotechnology over the last 30 years or 
so in terms of the relations among science, state, and society.

In the following subsequent sections, typical debates concerning public engagement on Japanese policy-making concerning GMOs are described and examined.

\section{Debates on public engagement during policy-making concerning GMOs in Japan}

In the food safety debates in Japanese ministries before 2001, issues of public engagement in policy development were seldom discussed. As one example, in the discussion of MHW from 1997-2001, only a few panels referred to two-way communication, and their opinions were not taken up as serious discussion topics. When public engagement was discussed, it was often in the context of risk analysis.

In contrast, debates on the enactment of the Cartagena Domestic Law and safety evaluation standards for GM foods saw two-way communication and public engagement in policy-making becoming important themes. These debates were held by the expert committees of the relevant Japanese ministries. Sub-committees which discussed these laws are shown in TABLE. 1. Most of the debates held in the course of the policy development were recorded as conference minutes (see TABLE. 1). Typical examples are cited below (the number after each statement reflects the sub-committees listed in TABLE. 1).

It is important to encourage mutual exchanges of information regarding the results of risk evaluations between the public and experts (Scientist/4).

Since risk-communication is an important process in risk evaluation, the information disclosure and the transparency of procedures are essential. In particular, it is necessary to disclose how the results of risk evaluations were obtained. It is also necessary to make every effort to provide plain explanations and to encourage stakeholders to participate in mutual dialogue, so that non-experts can understand the results of risk evaluations (Consumer organization representative/4).

In keeping with international debates surrounding CODEX and the enactment of the Cartagena Protocol, Japanese policies on GMOs appearing after 2000 emphasized the importance of two-way communication, reflecting a turning point in the attitude towards public engagement in Japanese science and technology policy-making. This 
shift is demonstrated in several important government documents and statements published by governments after 2000 (CSTP 2001, 2006, RECRBP 2002, MEXT 2004, MAFF 2005, 2007, Yamamoto and Kobayashi 2006).

\section{Japanese public engagement during policy-making concerning GMOs}

In Japanese policy-making concerning GMOs, the collection of public comment, public meetings, information disclosure, and consensus conferences are the major activities.

Concerning collection of public comment, an Administrative Procedure Law enacted in 1993 mandated the collection of public comment in Japanese policy-making. As a result, collection of public comments is conducted often.

In the course of enacting the current regulatory system on GMOs in Japan, the importance of collecting public comment was often emphasized as follows:

The process of collecting public comments is essential to reinforce the social trust and scientific validity of [risk] evaluations (Sociologists/4).

Collecting public comments concerning GMOs should be carried out (Company staff/ 5).

Public comment was thought to be necessary to retain social trust and maintain fairness in these discussions. Although there was a general consensus among the participants that the collection of public comment was an essential procedure in policy development, some pointed to negative aspects of the task.

Although I often dutifully submit public comments, it appears that governmental responses are often generated in a cut-and-paste fashion so that we tend to lose the motivation to submit our opinions (Consumer organization representative/3).

Although we submitted the opinions of the public and experts not involved in policy-making decisions, the respondents felt that their opinions were ignored in the process of policy-making. This led to distrust in prior risk evaluations (Sociologists/4).

These statements are indicative of general concerns that policy decisions inadequately 
reflect public comment and that this opinion has little impact on Japanese science and technology policy development. This problem is evident in the contexts of other public engagement in science and technology policy in Japan such as consensus conferences (Nishizawa 2005).

In Japan, a consensus conference on GM crops was convened in 2000 by the Society for Techno-invention of Agricultures, Forestry and Fisheries (STAFF) and by MAFF (Kobayashi 2004, Nishizawa 2005). It attracted the attention of policy-makers and researchers, and was thought to represent a new attempt by the Japanese government to engage the public in the decision making process. However, several comments in the course of establishing the policies of the Cartagena Domestic Law expressed a different view of proceedings. For example:

I think that the consensus conference convened by STAFF succeeded in facilitating independent discussions and outcomes, however, not a few people regarded it as a ritual to justify government decisions (Sociologist/4).

This statement seems to suggest that policy decisions inadequately reflected the outcome of the consensus conference, and this problem has been pointed out in other previous studies (e.g. Nishizawa 2005).

In November 2006 and February 2007, another consensus conference on GMO crops issues was convened by the government of Hokkaido prefecture. Representatives of the general public participated in serious discussions that reflected various viewpoints. This conference garnered the attention of various stakeholders due to the unique situation encountered in Hokkaido where the local government of the Hokkaido prefecture enforced strict rules for the use of GMOs in fields after 2004. Although the local government of Hokkaido declared that it would consider the key messages from the consensus conference in its policy decisions on GMOs (Kobayashi 2007), this intention has yet to be translated into reality. Consequently, a lack of input by the public into policy decisions constitutes a common weakness in Japanese science and technology policy-making.

The current Japanese laws regulating the use of GMOs also require mutual exchanges with farmers and the public. Therefore, both national research institutes on GMOs and related administrations (e.g. FSC-RCEC) conducted many public meetings featuring question-and-answer sessions. However, the main participants in these meetings were local policy-makers, company staff, and journalists and the meetings became little more than an opportunity to collect information. As a result, they 
functioned as one-way communication systems. In addition, the low attendance rate by farmers, members of the affected communities, and consumers has been a serious common problem by the present.

Rowe and Frewer (2000) suggested that transparency is one of the important criteria for evaluation of public engagement. They pointed out the importance of the public's ability to see the process of policy-making. The disclosure of scientific facts is also important. In Japan, the sharing of basic information was regarded as one of the most important elements of effective two-way communication (RECRBP, 2002). Thus there have been many debates in Japan emphasizing the importance of the information disclosure during the policy-making process. At the same time, the dearth of information disclosure in the past was criticized, and the importance of quality of information was stressed:

I think that the biggest reason for the current distrust of the public in the government is attributable to poor information disclosure in past public communications and policy-making (Local government officers/3).

\section{Selection of the information to be disclosed and attention to its quality and transparency are essential prerequisites for appropriate information disclosure (Consumer organization representative/4).}

Insufficient information disclosure is also reportedly a major problem in Japanese public engagements involving biotechnology (RECRBP 2002, Watanabe et al. 2005, STAFF 2006), and has resulted in damage to the public's faith with respect to the transparency of debates on risk evaluation, as well as a loss of trust in scientists, policy-makers, and other experts. For information disclosure to be effective, there must be sufficient information and this should be readily accessible. This point has also been taken up as an important issue in several public engagements like consensus conferences (Einsiedel et al. 2001, Kobayashi 2004). Differences in both the needs and backgrounds of people who receive the information must also be considered.

\section{Discussion}

In this paper, the history of Japanese policies on GMO has been outlined. It can be seen that the current Japanese policy-making on GMOs has been developed based on careful 
discussions on the relationship between national and international contexts in the past.

It was shown that two-way communication among the various stakeholders came to be one of the most important themes of the Japanese current science and technology policy. This is the most obvious change in the Japanese science and technology policy-making over the last few years. Kiba (2000) stressed - when referring to the consensus conference convened by the STAFF - that an important function of two-way communication is visualization of existing problems. However, effective public engagement in policy-making does not yet exist in Japan, this despite repeated emphasis on the importance of such public engagement.

Rowe and Frewer (2005) proposed a typology of public engagement mechanisms which comprised public consultation, public communication, and public participation. According to Rowe and Frewer, the collection of public comment, information disclosure, and public meetings (with question and answer sessions) are categorized as public communication. In this way, the consensus conferences held by the STAFF and the government of Hokkaido prefecture can be seen as examples of public participation in Japanese policy-making. However, policy decisions are still not seen as adequately reflecting the outcome of consensus conferences. Therefore, it seems that most of attempts at public engagement in Japan are concerned with one-way communication.

It appears that one of the reasons why public engagement does not impact on policy is the lack of a system for evaluation of the outcomes of public engagement. To address inadequate inclusion of public concerns in policy development, the role and evaluation of public engagement need to be assessed. Outside Japan, this topic has been addressed both theoretically and practically and remains a key issue. Rowe and Frewer (2000, 2004) discussed criteria for evaluation of the effectiveness of public engagement focusing on specific examples (Rowe et al. 2004, Rowe and Frewer 2005). This is also important in the context of Japanese science and technology policy-making. The effectiveness of public engagement should be examined and discussions on a framework of evaluation are needed.

There is other possibility for further research. It would be interesting to analyze discussions on risk evaluation regarding GM foods safety and environmental effects of field testing of GM crops (e.g., Nora and Sheldon, 2003). Although Japan has, like Europe, a strict regulatory system for GM foods, Japan is also very active when it comes to authorizing the safety of such foods (Matsuo 2008). This is one of the most interesting features of the Japanese situation concerning GMOs. In addition, field tests of GM crops have been conducted and these tests have become a hot topic for the media. 
(Shineha et al. 2008). In Japan, discussion papers on the evaluation of the safety of GM foods and the environmental effects have also appeared on homepages of relevant administrations. These could be useful when considering Japanese discussions on GMOs. Examining current research on the relationship between Japanese policies and international guidelines like TFFDB (e.g. Matsuo et al. 2008) will give useful insights for the research on the decisions of individual evaluations.

One area of historical research still remains - an analysis of the details of interactions between Japanese policy contexts and international contexts. After the 1980s, Japanese guidelines were revised repeatedly. There is a possibility that international contexts affected revisions of Japanese guidelines. To make clear the interaction between policies, international comparison of regulatory framework and discussions during policy-making should be conducted. At the same time, features of Japanese political culture should be taken into consideration. Jasanoff (2005) compared the regulatory framework and ethical discussions on biotechnology in the USA, UK, and Germany over the last 30 years, and highlighted the cross-national difference of the element of political culture between those countries. The work serves as a useful reference. More detailed research on the feature of Japanese politics on biotechnology through international comparison is our next task.

\section{Conclusion}

This paper argues that the turning point for Japanese policy-making on GMOs occurred in around 2001 and that after that date, debates on the desirability of public engagement were included in the development of policies promulgated by the Japanese science and technology agencies. The importance of public engagement in policy development is now accepted by experts involved in policy-making. However, many problems remain with respect to public engagement in GMO issues. One of the most significant problems is the absence of the adequate reflection of public engagement in policy-making and this still needs to be addressed. Further debate regarding the validity, evaluation, and importance of public engagement is also needed.

\section{Acknowledgments}

This article is based on our presentation at the Conference 'Genetics and Society: 
Retrospectives and Prospects' CESAGen/CSG 4th International Conference. We thank A. Hibino, H. Hirakawa, and U. Petralia for their insightful advice. This work was supported by a Grant-in-Aid for Scientific Research on Priority Areas "Applied Genomics" from the MEXT to K. Kato and "Research and Development for Deliberation and Cooperation between Citizens and Scientists" from the Research Institute for Science and Technology for Society (RISTEX), Japan Science and Technology Agency of Japan (JST) to H. Hirakawa.

\section{References}

Bredahl, L., 1999 Consumers' cognitions with regard to genetically modified foods. Results of a qualitative study in four countries. Appetite, 33c(3), 343-360.

BSC 2002, Biotechnology Strategy Guidelines - Three Strategies Opening the Way to Vast Improvements in Three Basic Aspects of the Human Experience: Our Health, Our Food, Our Lifestyles.

Available from:

http://www.biojapan.org/industry/reports/Biostrategy.pdf >

CSTP 2001, The 2nd Science and Technology Basic Plan.

Available from:

http://www8.cao.go.jp/cstp/english/basic/2nd-BasicPlan_01-05.pdf

CSTP 2006, The 3rd Science and Technology Basic Plan.

Available from:

http://www8.cao.go.jp/cstp/english/basic/3rd-Basic-Plan-rev.pdf

Einsiedel, E. F., Jelsoe, E., Breck, T. 2001. Publics at the technology TABLE: The consensus conference in Denmark, Canada, and Australia. Public

Understanding of Science, 10 (1), pp. 83-98

FAO 1998, The application of risk communication to food standards and safety matters. Available from: ftp://ftp.fao.org/docrep/fao/005/x1271e/x1271e00.pdf

Frewer, L., 2004. The public and effective risk communication. Toxicology Letters, 149 (1-3), 391-397. 
Frewer, L., et al., 2004. Societal aspects of genetically modified foods. Food and Chemical Toxicology, 42 (7), 1181-1193

Gaskel G., et al., 2006. Transatlantic Tensions over GM Crops and Food. In M. Bauer and G. Gaskell, eds. Genomics and Society. London: Earthscan, 197-211

Gaskell, G., 2004. Science policy and society: the British debate over GM agriculture. Current Opinion in Biotechnology, 15 (3), 241-245.

Gaskell, G., Allum, N., et al. 2000. Biotechnology and the European public. Nature Biotechnology, 18 (9), 935-938.

Hino, A., 2002. Safety assessment and public concerns for genetically modified food products: The Japanese experience. Toxicologic Pathology, 30 (1), 126-128.

Hoban, T. J., 1997. Consumer acceptance of biotechnology: An international perspective. Nature Biotechnology, 15 (3) 232-234.

Ichikawa, K., 2002. Genetically Modified Food and Food Labeling. Journal of Nagoya Bunri University, 2, 101-111.

Inaba, M. M., DRJ., 2003. Attitudes to biotechnology in Japan in 2003. Eubios Journal of Asian and International Bioethics, 13, 78-89.

James, C., 2007 ISAAA Brief 35-2006: Executive Summary Global Status of Commercialized Biotech/GM Crops: 2006 Available from: http://www.isaaa.org/resources/publications/briefs/35/executivesummary/default .html

Jasanoff, S. 2005. Designs on Nature: Science and Democracy in Europe and the United States. Princeton: Princeton University Press.

Jo, A. B., Timothy, H., Heather, S., 2003. Public perception of plant biotechnology - a focus group study. New Genetics and Society, 22 (2), 93-109.

Kiba, T., 2000. A Consideration on the Formation Process and Social Meaning of Consensus Conferences (in Japanese). The Journal of Science Policy and Research Management, 15 (2), 122-131. 
Kobayashi, T. 2004. Who Thinks Science and Technology? (in Japanese). Nagoya: University of Nagoya Press.

Kobayashi, T. 2007. The Era of Trans Science - Connect Science and Technology to Society (in Japanese). Tokyo: NTT Press.

Macer, D. and Ng M. A. C., 2000. Changing attitudes to biotechnology in Japan. Nature Biotechnology, 18 (9), 945-947.

Macer, D. R. J. 1992. Attitudes to Genetic Engineering Japanese and International Comparisons. Christchurch: Eubios Ethics Institute.

Kato, Y. and Macer, D. R. J., 1994. Bioethical Reasoning in Japan. In Macer, D. R. J, ed. Bioethics for the People by the People. Christchurch: Eubios Ethics Institute, $146-150$.

MAFF, 2005. Basic Plan for Agriculture, Forestry and Fisheries Research (in Japanese).

Available from:

http://www.s.affrc.go.jp/docs/press/2005/0331a/press_050331a.pdf

MAFF (2007) Basic Plan for Agriculture, Forestry and Fisheries Research (in Japanese).

Available at $<$ http://www.s.affrc.go.jp/docs/kihonkeikaku/zenbun.pdf $>$

Matsuo, M., Shiroyama, H., Imamura, T., 2008. Low Level Presence of Unauthorized GM Plant Material in Food - An Analysis on the Past Cases (in Japanese). Food Sanitation Research, 58 (2), 27-37.

Matsuo, M., 2008. Dynamics of international agreement on food safety - case study of Genetically Modified foods (in Japanese). In Shiroyama H., ed. Politics of Science and Technology. Tokyo: Tokyo University Press, 191-224.

METI, 2006 Survey of the Bio Industry 2005 (in Japanese).

Available from: http://www.meti.go.jp/policy/bio/

MEXT, 2004. White Paper on Science and Technology 2004 Science and Technology and Society in the Future.

Available from:

http://www.mext.go.jp/english/news/2005/04/05051301.htm

Ng MA, T. C., Watanabe T, Macer D., 2000. Attitudes of the public and scientists to 
biotechnology in Japan at the start of 2000. Eubios Journal of Asian and International Bioethics, 10, 106-113.

Nishizawa. M., 2005. Citizens deliberations on science and technology and their social environments: case study on the Japanese consensus conference on GM crops. Science and Public Policy, 32 (6), 479-489.

Nora, M., Sheldon, K., 2003. Implicit precaution, scientific inference, and indirect evidence: the basis for the US Environmental Protection Agency's regulation on genetically modified crops. New Genetics and Society, 22 (2), 127-143.

RECRBP, 2002. (in Japanese).

Available from:

http://www.maff.go.jp/soshiki/seisan/eisei/bse/bse_tyosaiinkai.pdf

Rowe, G., and Frewer, L.J., 2000. Public Participation Methods: A Framework for Evaluation. Science Technology \& Human Values, 25 (1), 3-29.

Rowe, G. and Frewer, M. L. J., 2004. Evaluating Public-Participation Exercises: A Research Agenda. Science Technology \& Human Values, 29 (4), 512-557.

Rowe, G. Roy. M, and Frewer, L. J., 2004. Evaluation of a Deliberative Conference. Science Technology \& Human Values, 29 (1), 88-121.

Rowe, G. and Frewer, L. J., 2005. A typology of public engagement mechanisms. Science Technology \& Human Values, 30 (2), 251-290.

Saegusa, A., 1999(a). Japan tightens rules on GM crops to protect the environment. Nature, 399 (6738), 719-719.

Saegusa, A., 1999(b). Japan plans to label 'detectable' GM food. Nature, 400 (6745), $605-605$.

Saegusa, A., 2000. GM food regulatory terms debated. Nature Biotechnology, 18 (5), $484-485$.

Saito, H., 1995. The National Promotion of "life-science" (in Japanese) The Social History of Science \& Technology in Contemporary Japan, (4), 315-331

Sasa, Y. and Watanabe, K., 2006. The Present Situation of the Public Acceptance in 
Genetically Modified Crops and Food Products. Breeding Research, 18 (3), 99-105

Shineha, R. Hibino, A. Kato, K., 2008. Analysis of Japanese Newspaper Articles on Genetic Modification. Journal of Science Communication, 2, 2008. Available from: http://jcom.sissa.it/archive/07/02/Jcom0702(2008)A02/

STAFF (2006) Research report 2006 (in Japanese).

Available from:

http://web.staff.or.jp/data/ivent/200603/20-2006032211531309821.pdf

Uozum, Y., 1999. Japan to bring in mandatory tests for GM foods. Nature, 402 (6764), 846-846.

Uzogara, S. G., 2000. The impact of genetic modification of human foods in the 21st century: A review. Biotechnology Advances, 18 (3), 179.

Watanabe, K N., S. Y., Suda E, Chen C, Inaba M, Kikuchi A., 2005 Global political, economic, social and technological issues on transgenic crops. Plant Biotechnology, 22 (5), 515-522.

Watanabe, K. N., Taeb, M., et al. 2004. Japanese controversies over transgenic crop regulation. Science, 305 (5690), 1572-1572.

Yamamoto, S., and Kobayashi, S., 2006. Research report of the methods for the public acceptance of GMOs (in Japanese, not open accessed).

Yamanouchi, K., 2005. Regulatory considerations in the development and application of biotechnology in Japan. Revue Scientifique Et Technique. 24 (1), 109-115.

Yamanouchi, K., 2007. Regulatory considerations on transgenic livestock in Japan in relation to the Cartagena protocol. Theriogenology, 67 (1), 185-187. 


\begin{tabular}{|c|c|c|c|}
\hline Ministry name & Previous name & Research target & URL \\
\hline $\begin{array}{l}\text { Ministry of Education, } \\
\text { Culture, Sports, Science and } \\
\text { Technology (MEXT) }\end{array}$ & $\begin{array}{l}\text { Ministry of Education } \\
\text { (MONBU), Science and } \\
\text { technology Agency (STA) }\end{array}$ & $\begin{array}{l}\text {-Sub-Committee for } \\
\text { Research and Development } \\
\text { on Living Modified Organisms } \\
\text { (LMOs) }\end{array}$ & http://www.mext.go.jp/ \\
\hline $\begin{array}{l}\text { Ministry of Agriculture, } \\
\text { Forestry and Fisheries of } \\
\text { Japan (MAFF) }\end{array}$ & $\begin{array}{l}\text { Ministry of Agriculture, } \\
\text { Forestry and Fisheries of } \\
\text { Japan (MAFF) }\end{array}$ & $\begin{array}{l}\text {-Meeting for the Risk } \\
\text { Management of the Adverse } \\
\text { Effect on the Environment of } \\
\text { GM Crops } \\
3 \text {-Sub-Committee on the } \\
\text { Development of Guidelines } \\
\text { for the Filed Testing of LMOs } \\
\text { with Approval of Type } 1 \text { Use } \\
\text { Regulations }\end{array}$ & http://www.maff.go.jp/ \\
\hline $\begin{array}{l}\text { Ministry of Economy, Trade } \\
\text { and Industry (METI) }\end{array}$ & $\begin{array}{l}\text { Ministry of International } \\
\text { Trade and Industry (MITI) }\end{array}$ & \begin{tabular}{|l|} 
4-Sub-Committee for \\
Management of LMOs
\end{tabular} & http://www.meti.go.jp/index.html \\
\hline $\begin{array}{l}\text { Ministry of the Environment } \\
\text { (MOE) }\end{array}$ & Environmental Agency & 5-Sub-Committee for LMOs & http://www.env.go.jp/ \\
\hline $\begin{array}{l}\text { Food Safety Commission } \\
\text { (FSC) }\end{array}$ & & $\begin{array}{l}\text { 6-Genetically Modified Foods } \\
\text { Expert Committee } \\
\text { 7-Risk Communication } \\
\text { Expert Committee } \\
\end{array}$ & http://www.fsc.go.jp/ \\
\hline $\begin{array}{l}\text { Ministry of Health, Labor and } \\
\text { Welfare (MHLW) }\end{array}$ & $\begin{array}{l}\text { Ministry of Health and } \\
\text { Welfare (MHW) }\end{array}$ & \begin{tabular}{|l|} 
8-Food Sanitation \\
Investigation Council Task \\
Force on Biotechnology \\
9-Food Sanitation \\
Investigation Council Task \\
10-Food Sanitation \\
Investigation Council \\
Permanent Committee \\
11-Department of Food \\
Safety, Pharmaceutical and \\
Food Safety Bureau \\
\end{tabular} & http://www.mhlw.go.jp/ \\
\hline
\end{tabular}

TABLE 1. Ministries regulating the use of GMOs 
Research and Developmemt

Catagena Domestic Law

Type1 MAFF and MOE regulate

Use without containment measures

(Field testing)

Type2 MEXT and MOE regulate

Use with containment measures (Use in labolatories)
Food and Feed Use of GMOs

Food Safety Basic Law

Safety evaluation of GM food

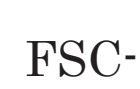

Request advice

GMFEC

Report

Safety evaluation of GM feed

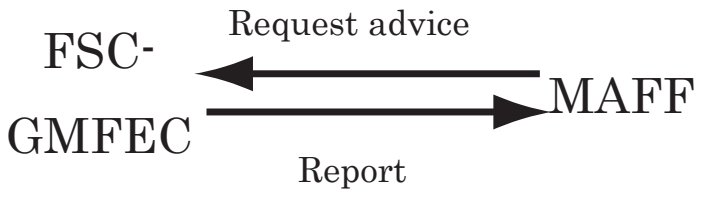

FIGURE 1. Outline of the current regulatory system for the use of GMOs MEXT: Ministry of Education, Culture, Sports, Science and Technology, MOE: Ministry of the Environment MAFF: Ministry of Agriculture, Forestry and Fishries of Japan, MHLW: Ministry of Health, Labour, and Welfare FSC-GMFEC: Food Safety Commission Genetically Modified Foods Expert Committee 


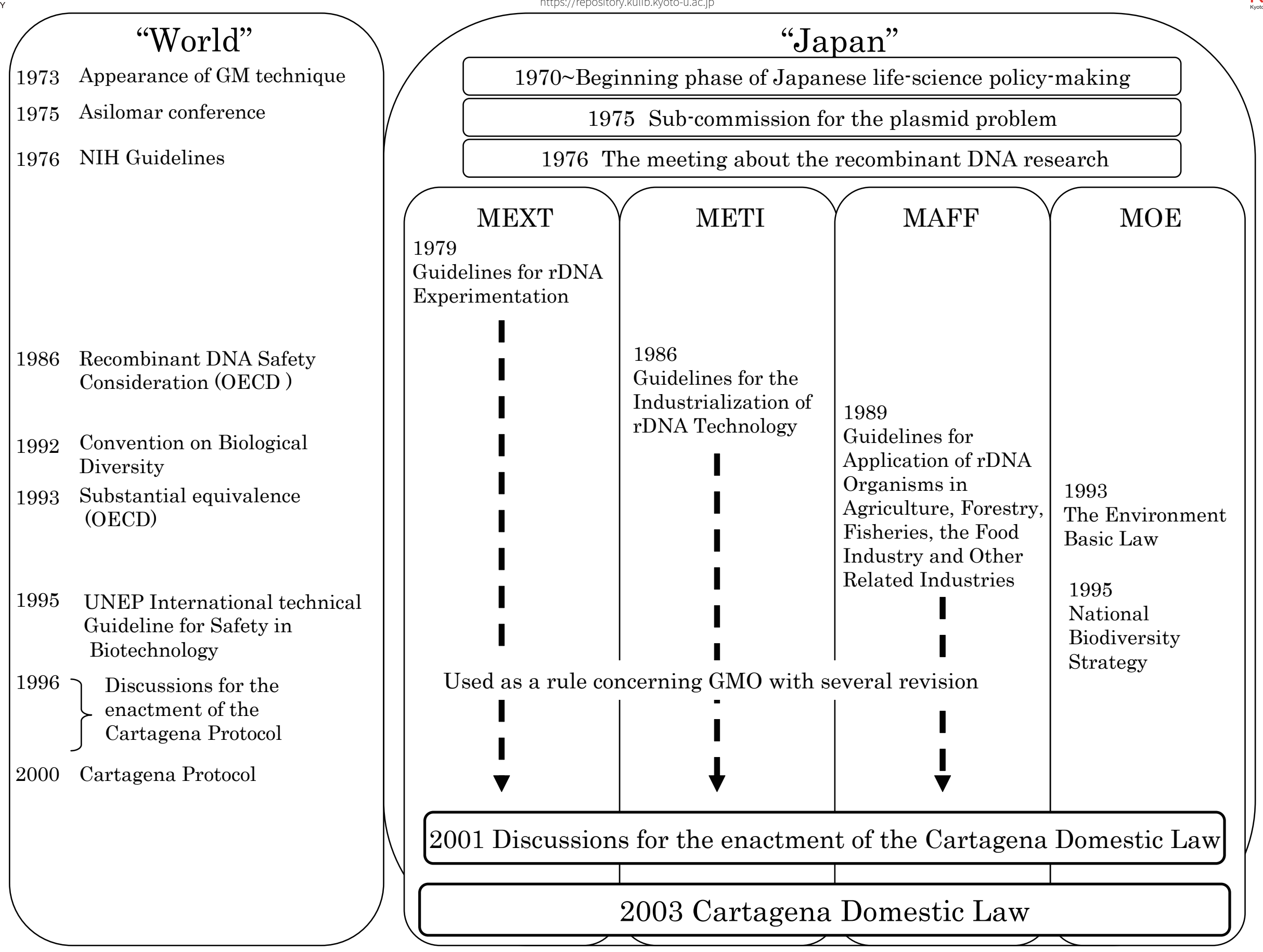

FIGURE 2. Outline of the history of the Cartagena Domestic Law 


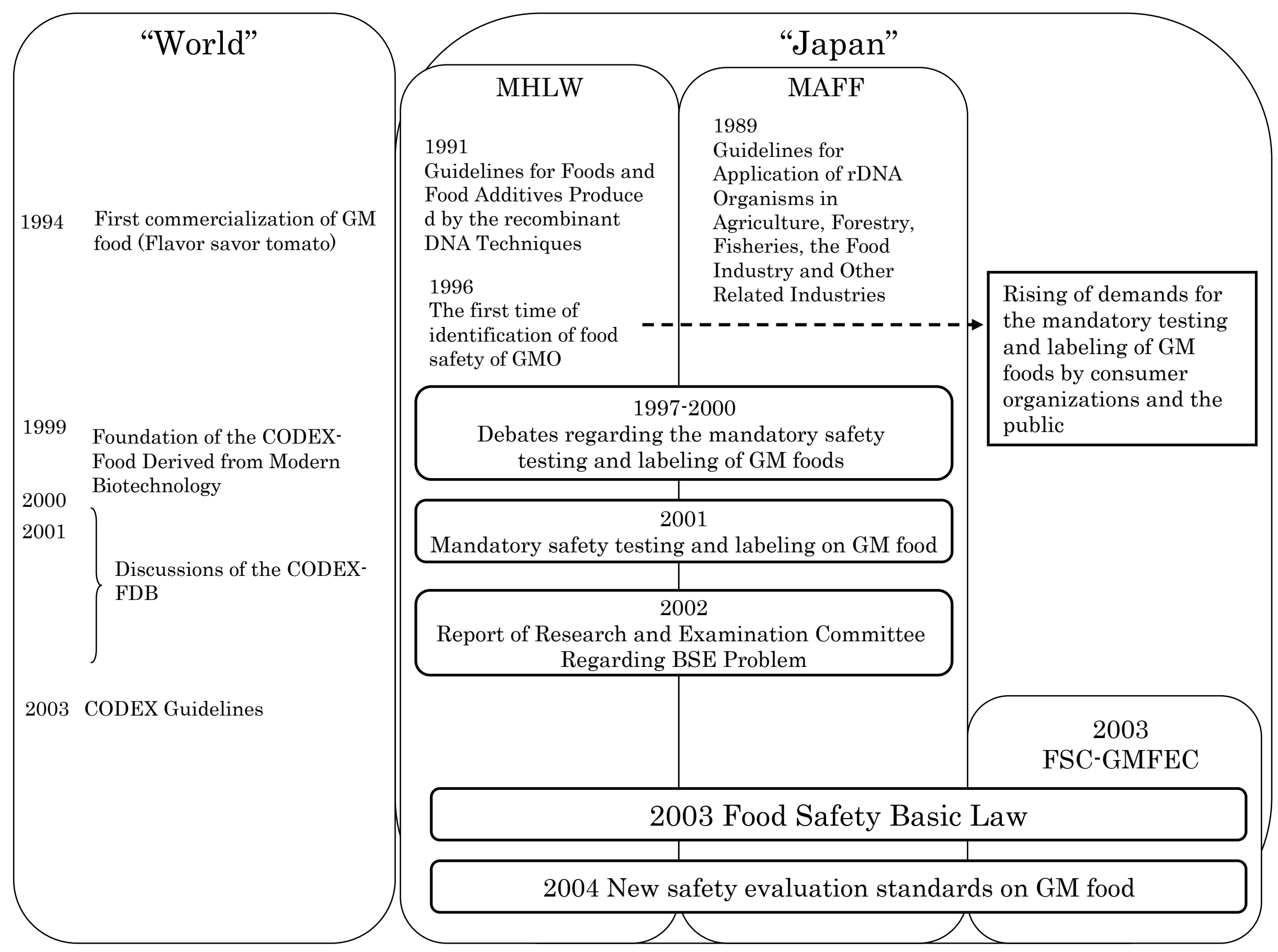

FIGURE 3. Outline of the history of the Food Safety Basic Law 